\title{
Severe low cerebral oximetry in difficult cardiopulmonary bypass weaning of low body-weight infant: a case report and literature review
}

\author{
Xuechao Hao and Wei Wei ${ }^{*}$
}

\begin{abstract}
Background: For infants undergoing complex cardiac surgery, hemodynamic management after cardiopulmonary bypass (CPB) is challenging because of severe myocardial edema, vasomotor dysfunction and weak tolerance to a change in blood volume. More importantly, the lack of availability of equipment for advanced monitoring, such as transesophageal echocardiography or transthoracic echocardiography, restricts the accurate assessment of hemodynamics.

Case presentation: This is a case of severe hypotension and non-detectable pulse oxygen saturation $\left(\mathrm{SpO}_{2}\right)$ after CPB in a low-weight infant who had normal blood pressure and oxygen saturation before surgery. Epinephrine and milrinone were administered with cerebral oximetry monitoring rather than blood pressure measurements because cerebral oximetry was more responsive to treatment than blood pressure. Under the guidance of cerebral oximetry, the infant was successfully weaned from CPB and recovered after surgery without adverse neurological events.

Conclusions: For infants who develop refractory hypotension and failure in $\mathrm{SpO}_{2}$ monitoring during the $\mathrm{CPB}$ weaning period, cerebral oximetry provides an index for assessing brain perfusion and valuable guidance for appropriate inotropic treatment.
\end{abstract}

Keywords: Cerebral oximetry, Cardiopulmonary bypass, Low body-weight infant, Vasoconstrictor

\section{Background}

For an infant undergoing complex cardiac surgery, hemodynamic management after cardiopulmonary bypass $(\mathrm{CPB})$ is challenging because of severe myocardial edema, vasomotor dysfunction and weak tolerance to a change in blood volume [1]. More importantly, lack of availability of equipment for advanced monitoring, such as transesophageal echocardiography or transthoracic echocardiography, restricts the accurate assessment of

\footnotetext{
* Correspondence: 453601718@qq.com

Department of Anesthesiology, The Research Unit of Perioperative Stress Assessment and Clinical Decision (2018RU012), Chinese Academy of Medical Sciences, West China Hospital, Sichuan University, 610041, Chengdu, People's Republic of China
}

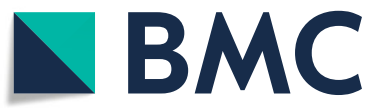

(0) The Author(s). 2020 Open Access This article is licensed under a Creative Commons Attribution 4.0 International License, which permits use, sharing, adaptation, distribution and reproduction in any medium or format, as long as you give appropriate credit to the original author(s) and the source, provide a link to the Creative Commons licence, and indicate if changes were made. The images or other third party material in this article are included in the article's Creative Commons licence, unless indicated otherwise in a credit line to the material. If material is not included in the article's Creative Commons licence and your intended use is not permitted by statutory regulation or exceeds the permitted use, you will need to obtain permission directly from the copyright holder. To view a copy of this licence, visit http://creativecommons.org/licenses/by/4.0/. The Creative Commons Public Domain Dedication waiver (http://creativecommons.org/publicdomain/zero/1.0/) applies to the data made available in this article, unless otherwise stated in a credit line to the data.

\section{Case presentation}

A female infant aged 2 months, weight $2.7 \mathrm{~kg}$, height 50 $\mathrm{cm}$, diagnosed with ventricular septal defect (VSD), atrial

hemodynamics [2]. This case describes the emergency rithm of hemodynamic management using cerebral oximetry as the main monitoring tool during cardiac surgery with $\mathrm{CPB}$ in infants, especially during the $\mathrm{CPB}$ weaning period. 
septal defect (ASD) and severe pulmonary hypertension was scheduled for VSD repair under CPB. The preoperative TTE examination revealed a VSD of $9 \mathrm{~mm}$ and an ASD of $8 \mathrm{~mm}$. The past medical or family history was unremarkable.

General anesthesia was induced by $0.5 \mathrm{mg}$ midazolam, $5 \mu \mathrm{g}$ fentanyl, $5 \mathrm{mg}$ rocuronium and $7 \%$ sevoflurane. An endotracheal tube with an inner diameter of $3 \mathrm{~mm}$ was intubated using direct laryngoscope. After tracheal intubation, the infant was ventilated to normocapnia with an inspired oxygen fraction 0.5 by a fresh gas flow of 2 $\mathrm{L} / \mathrm{min}$ of oxygen and air. Anesthesia was maintained with sevoflurane inhalation, intravenous infusion of remifentanil and injection of fentanyl and rocuronium as required. Invasive arterial blood pressure was continuously monitored through the left radial artery. The patient had a $5 \mathrm{~F}$ double-lumen catheter placed in the right internal jugular vein for central venous pressure monitoring and medication. The arterial blood gas analysis after intubation (before surgery) was: $\mathrm{pH} 7.34$, carbon dioxide partial pressure $\left(\mathrm{PCO}_{2}\right) 39.5 \mathrm{mmHg}$, oxygen partial pressure $\left(\mathrm{PO}_{2}\right) 218.8 \mathrm{mmHg}$ and haemoglobin $82.4 \mathrm{~g} / \mathrm{L}$. TEE monitoring was not performed due to no available probe for an individual weighing less than $3 \mathrm{~kg}$. Arterial blood pressure was $64 / 40 \mathrm{mmHg}$, and the $\mathrm{SpO}_{2}$ signal was good and the reading was $100 \%$ prior to surgery. Anesthesia and surgical repair were performed routinely. The operative site was exposed via a median sternotomy, then $\mathrm{CPB}$ was built successfully after injection of $1125 \mathrm{U}$ heparin and cannulation at the aorta root, superior vena cava and inferior vena cava, with infusion of cardioplegia solution containing potassium. The core body temperature was maintained at $32 \sim 33^{\circ} \mathrm{C}$ during $\mathrm{CPB}$. The ASD and VSD were patched during $88 \mathrm{~min}$ of aortic cross-clamp period. The results of arterial or venous blood gas analysis during surgery are shown in Supplementary file Table 2.

After the aortic clamp was released, sinus rhythm was restored spontaneously at a rate of 120 to 130 beats per minute and the electrocardiogram showed ST segment elevation. Intravenous infusions of epinephrine and nitroglycerin were administered at a dose of $0.05 \mu \mathrm{g} /$ (kg.min) and $0.5 \mu \mathrm{g} /(\mathrm{kg} \cdot \mathrm{min})$, respectively. When bypass withdrawal was attempted, sustained hypotension and low saturation of blood oxygen occurred. The systolic blood pressure ranged between $40 \sim 50 \mathrm{mmHg}$ and a $\mathrm{SpO}_{2}$ value at the finger could not be detected. An oximetry probe was attached to the ear of the infant for $\mathrm{SpO} 2$ monitoring, but no signal was detectable. The arterial blood gas analysis revealed a $\mathrm{PaO}_{2}$ of $35.4 \mathrm{mmHg}$, $\mathrm{PaCO}_{2}$ of $43.2 \mathrm{mmHg} \mathrm{Hb}$ and a hemoglobin concentration of $100.5 \mathrm{~g} / \mathrm{L}$. There was severe myocardial edema and this made the size of the heart exceed the pericardial cavity. The rate of the epinephrine intravenous infusion was increased to $0.1 \mu \mathrm{g} /(\mathrm{kg} \cdot \mathrm{min})$, but no significant increase in blood pressure occurred. A systolic blood pressure below $50 \mathrm{mmHg}$ is insufficient for satisfactory perfusion of body organs. As CPB had been completed and the aortic cannula removed, pressure detection at aortic root was not performed. Cerebral oximetry (Engin Bio-medical Electronics Co., Ltd., Suzhou, China) was applied to the left side to evaluate cerebral perfusion and revealed a cerebral tissue oxygen saturation $\left(\mathrm{SctO}_{2}\right)$ of $35.7 \%$.

Given the low blood pressure, low arterial blood oxygen saturation, and the low $\mathrm{SctO}_{2}$, poor cardiac output was considered as the likely cause. Therefore, the rate of epinephrine infusion was increased to $0.12 \mu \mathrm{g} /(\mathrm{kg} \cdot \mathrm{min})$ and milrinone was infused intravenously at a rate of $1 \mu \mathrm{g} /(\mathrm{kg} . \mathrm{min})$. After $20 \mathrm{~min}$ of inotropic treatment, the $\mathrm{SctO}_{2}$ increased gradually from 35.7 to $61 \%$, and photoplethysmography measurements from the finger and ear were now detectable and $\mathrm{SpO}_{2}$ increased to $98 \%$, but notably without a significant increase in blood pressure. Given the acceptable cerebral tissue oxygen saturation and $\mathrm{SpO}_{2}$, no further treatment was performed to increase blood pressure. When the infant transferred to the pediatric intensive care unit, the $\mathrm{SctO}_{2}$ was about $56 \%$, with a $\mathrm{SpO}_{2}$ of $99 \%$ and arterial blood pressure 48/ $29 \mathrm{mmHg}$. Epinephrine was infused at a rate of $0.1 \mu \mathrm{g} /$ (kg.min) and milrinone at $0.5 \mu \mathrm{g} /(\mathrm{kg} \cdot \mathrm{min})$. Arterial blood pressure, $\mathrm{SpO}_{2}$ and $\mathrm{SctO}_{2}$ readings are shown in Fig. 1 . An infusion of $170 \mathrm{~mL}$ crystalloid fluid was administered and $100 \mathrm{~mL}$ urine was output during the course of general anesthesia $(7.2 \mathrm{~h})$. Because of severe myocardial swelling, the thorax was only closed 3 days later. This infant was followed-up 3 months later and no neurological complications had occurred.

\section{Discussion and conclusions}

In this report, we have described a case of cerebral oximetry measurements during $\mathrm{CPB}$ weaning and the medication administered without available $\mathrm{SpO}_{2}$ or TEE assisted hemodynamic measurements in an infant who developed a severe low blood pressure. Even though little increase of blood pressure occurred after treatment with a high dose of epinephrine and milrinone, an acceptable level of $\mathrm{SctO}_{2}$ was achieved. After delayed sternal closure, the infant was discharged from hospital without any discernible neurological complications. This case, which integrated the practical use of cerebral oximetry, raised several important issues worthy of discussion.

Cerebral tissue is highly vulnerable during $\mathrm{CPB}$ for its weak tolerance to hypoxia, even for a short period of time. Thus, cerebral injury is a common complication after cardiac surgery $[3,4]$. As an essential target organ of the systemic circulation, the monitoring status of 


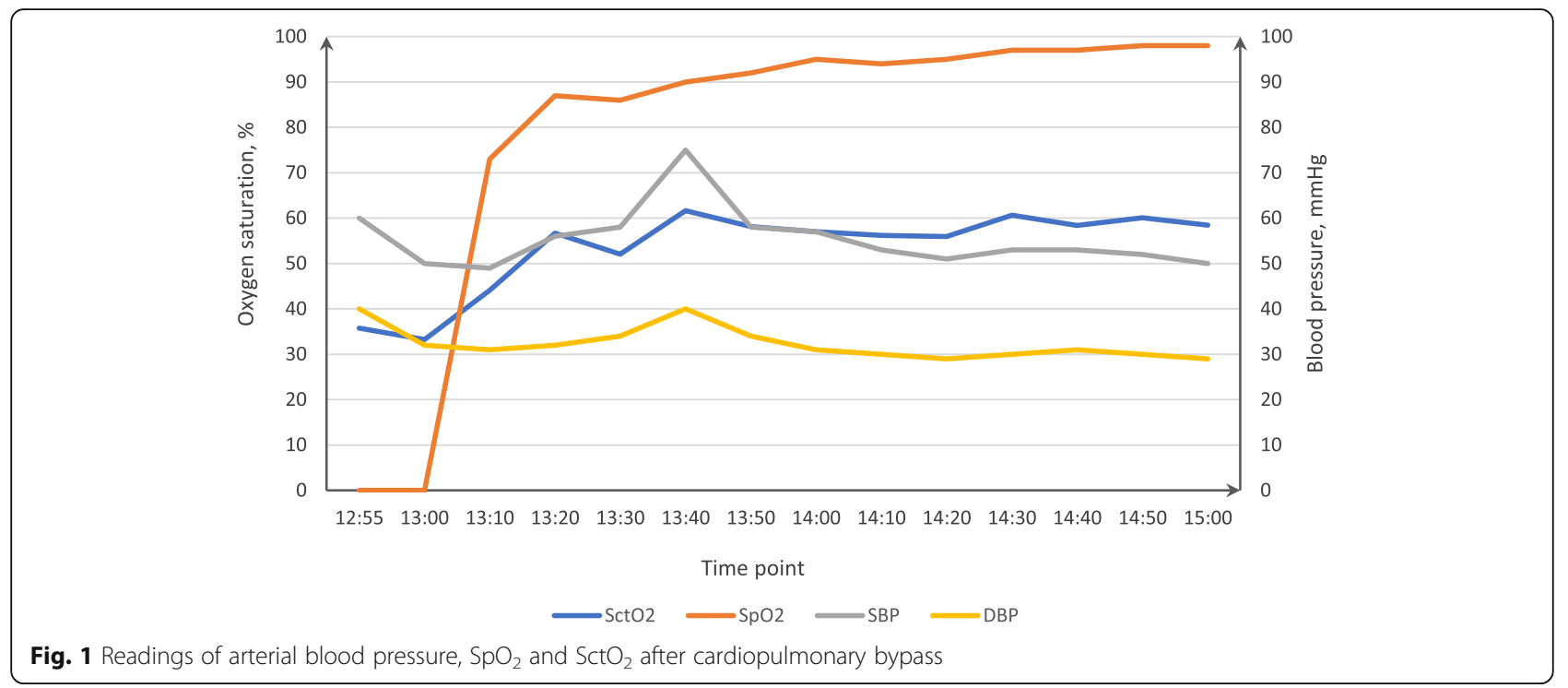

cerebral oxygen metabolism is of great significance for evaluating hemodynamic management. Over the past few decades, near-infrared spectroscopy based regional $\mathrm{SctO}_{2}$ monitoring has been widely used to estimate the balance between oxygen supply and consumption in cerebral tissue to a depth of about $15 \mathrm{~mm}$ [5]. A decrease in $\mathrm{SctO}_{2}$ is associated with postoperative cerebral injury, neurocognitive dysfunction, a prolonged hospital stay and increased cost [6].

The value of SctO2 is determined by two main factors, oxygen supply and oxygen consumption [7]. Changes in cardiac outflow, mean arterial pressure (MAP), intracranial pressure (ICP), venous return and oxygen saturation of arterial blood, are considered to be the main factors that affect cerebral oxygen supply. The degree of aerobic metabolism of cerebral tissue is also associated with oxygen consumption. As demonstrated in previous studies, maneuvers including optimizing blood pressure and cardiac output, maintaining an appropriate head position, end-tidal $\mathrm{CO}_{2}$ and hemoglobin levels, are commonly used to augment cerebral oxygen supply. In addition, intravenous anesthesia, hypothermia or anti-epileptic medication, are also options to decrease oxygen consumption of cerebral tissue $[5,6,8]$.

In the present case, the depth of anesthesia and the head position was unremarkable. Severe hypotension and myocardial edema were the main manifestations after CPD, accompanied by systemic hypoxia and a low $\mathrm{SctO}_{2}$. Given the severe myocardial edema, the reduction in blood pressure and $\mathrm{SpO}_{2}$ was mainly interpreted as being caused by a decrease in cardiac output. Therefore, epinephrine was first administrated, but had little effect on blood pressure [9]. Due to the low body weight, no available TEE probe could be used to understand further the etiology and to decide whether to continue cardiotonic therapy or administer norepinephrine to increase peripheral resistance. With $\mathrm{SctO}_{2}$ monitoring, $0.5-1 \mu \mathrm{g} / \mathrm{kg}$ milrinone was administered tentatively to increase cardiac output. Even though the blood pressure remained low after treatment, the $\mathrm{SctO}_{2}$ value was significantly increased.

It is likely that low blood pressure is an important cause of poor cerebral perfusion, based on the formula: cerebral perfusion pressure $=$ mean blood pressure - in tracerebral pressure. Increasing blood pressure is listed as the first parameter to consider for cerebral desaturation by proposed algorithms [5]. However, recent studies have revealed that a higher blood pressure did not produce an increase in $\mathrm{SctO}_{2}$. Holmgaard et al., reported that at a fixed cardiopulmonary bypass pump flow rate of $2.4 \mathrm{~L} / \mathrm{min} / \mathrm{m}^{2}$, targeting a high MAP $(70-80 \mathrm{mmHg})$ by norepinephrine produced more frequent and pronounced cerebral desaturation than a low MAP (40-50 $\mathrm{mmHg}$ ) during bypass [10]. Similar findings were also reported in previous studies [11, 12]. The effect of increasing MAP by raising the $\mathrm{SctO}_{2}$ level remains to be debated. Several studies have also shown the discrepancy in the effects of epinephrine and other vasoconstrictors such as phenylephrine on $\mathrm{SctO}_{2}[13,14]$. Even though epinephrine and milrinone elevated $\mathrm{SctO}_{2}$ in the present case, the controversy remains to be resolved.

However, because the baseline level of $\mathrm{SctO}_{2}$ was not measured before anesthesia or surgery, the normal range or target of therapy for this infant was unclear. Multiple studies have been conducted to determine the normal range of $\mathrm{SctO}_{2}[15,16]$. Kussman et al. reported in children with congenital heart disease that $\mathrm{SctO}_{2}$ ranged from 56 to $82 \%$ with a median of $73 \%$, which was affected by the hemoglobin concentration [15]. Nonetheless, $\mathrm{SctO}_{2}$ changes referring to baseline rather than 
absolute values are preferred in clinical practice or research studies $[17,18]$. Furthermore, the present case indicated that systemic oxygen saturation is correlated with $\mathrm{SctO}_{2}$, shown by the parallel increase in $\mathrm{SctO}_{2}$ and $\mathrm{SpO}_{2}$. But it should be noted that a large discrepancy between $\mathrm{SctO}_{2}$ and somatic tissue oxygen saturation was demonstrated in previous studies in adult surgical patients [19].

In conclusion, for an infant with difficult CPB weaning, especially one with a low cardiac output resulting in $\mathrm{SpO}_{2}$ monitoring failure, cerebral oximetry is applicable for evaluating and directing hemodynamic management. Appropriate treatment is based on meticulous analysis among the variables of blood volume, cardiac function, mean blood pressure, hypoxia, anemia, and so on. A further study will be necessary to evaluate the effects vasoconstrictor-induced increase in blood pressure on $\mathrm{SctO}_{2}$ and the underlying mechanisms.

\section{Supplementary information}

Supplementary information accompanies this paper at https://doi.org/10. 1186/s12871-020-01071-1.

Additional file 1: Table S1. Measurements of arterial blood pressure, $\mathrm{SpO}_{2}$ and $\mathrm{SctO}_{2}$, also shown in Fig. 1.

Additional file 2: Table S2. Results of blood gas analysis during surgery. 08:12 anesthesia induced; 09:40 surgery started; 10:28 CPB started; 10:43 aorta cross-clamped; 12:11 aorta clamp released; 12:50 CPB ended; 15:25 surgery ended. A, arterial blood; $V$, venous blood.

\section{Abbreviations}

ASD: Atrial septal defect; CPB: Cardiopulmonary bypass; TEE: Transesophageal echocardiography; ICP: Intracranial pressure; MAP: Mean arterial pressure; NIRS: Near-infrared spectroscopy; $\mathrm{PaCO}_{2}$ : Carbon dioxide partial pressure; $\mathrm{PO}_{2}$ : Oxygen partial pressure; $\mathrm{SctO}_{2}$ : Cerebral tissue oxygen saturation; $\mathrm{SpO}_{2}$ : Pulse oxygen saturation; TTE: Transthoracic echocardiography; VSD: Ventricular septal defect

\section{Acknowledgements}

Not applicable.

\section{Authors' contributions}

$\mathrm{XCH}$ collected the medical history and was a major contributor in writing the manuscript. WW analyzed and interpreted the patient data. All authors read and approved the final submitted manuscript.

\section{Funding}

None.

\section{Availability of data and materials}

All data generated or analyzed during this study are included in this published article and its additional information file.

\section{Ethics approval and consent to participate}

Not applicable.

\section{Consent for publication}

A written consent for publication was obtained from the parent of the infant.

\section{Competing interests}

The authors declare that there are no competing interests.
Received: 24 September 2019 Accepted: 11 June 2020

Published online: 27 June 2020

\section{References}

1. Epting CL, McBride ME, Wald EL, et al. Pathophysiology of post-operative low cardiac output syndrome. Curr Vasc Pharmacol. 2016;14:14-23.

2. Vincent JL, Pelosi P, Pearse R, et al. Perioperative cardiovascular monitoring of high-risk patients: a consensus of 12. Crit Care. 2015;19:224.

3. Roach GW, Kanchuger M, Mangano CM, et al. Adverse cerebral outcomes after coronary bypass surgery. Multicenter study of perioperative ischemia research group and the Ischemia Research and Education Foundation investigators. N Engl J Med. 1996;335:1857-63.

4. Liu Y, Chen K, Mei W. Neurological complications after cardiac surgery: anesthetic considerations based on outcome evidence. Curr Opin Anaesthesiol. 2019:32(5):563-7.

5. Denault A, Deschamps A, Murkin JM. A proposed algorithm for the intraoperative use of cerebral near-infrared spectroscopy. Semin Cardiothorac Vasc Anesth. 2007;11:274-81.

6. Casati A, Fanelli G, Pietropaoli P, et al. Continuous monitoring of cerebral oxygen saturation in elderly patients undergoing major abdominal surgery minimizes brain exposure to potential hypoxia. Anesth Analg. 2005;101(3): 740-7 table of contents.

7. Chen YJ, Wang JS, Hsu CC, et al. Cerebral desaturation in heart failure: potential prognostic value and physiologic basis. PLoS One. 2018;13: e0196299.

8. Deschamps A, Hall R, Grocott $\mathrm{H}$, et al. Cerebral Oximetry monitoring to maintain Normal cerebral oxygen saturation during high-risk cardiac surgery: a randomized controlled feasibility trial. Anesthesiology. 2016;124: $826-36$

9. Oualha M, Urien S, Spreux-Varoquaux O, et al. Pharmacokinetics, hemodynamic and metabolic effects of epinephrine to prevent postoperative low cardiac output syndrome in children. Crit Care. 2014;18:R23.

10. Holmgaard F, Vedel AG, Lange T, et al. Impact of 2 distinct levels of mean arterial pressure on near-infrared spectroscopy during cardiac surgery: secondary outcome from a randomized clinical trial. Anesth Analg. 2019; 128:1081-8

11. Moerman A, Denys W, De Somer F, et al. Influence of variations in systemic blood flow and pressure on cerebral and systemic oxygen saturation in cardiopulmonary bypass patients. Br J Anaesth. 2013;111:619-26.

12. Sperna WNH, Brevoord D, Jöbsis DA, et al. Cerebral oxygenation during changes in vascular resistance and flow in patients on cardiopulmonary bypass - a physiological proof of concept study. Anaesthesia. 2017;72:49-56.

13. Vanpeteghem CM, Bruneel BY, Lecoutere IM, et al. Ephedrine and phenylephrine induce opposite changes in cerebral and paraspinal tissue oxygen saturation, measured with n-infrared spectroscopy: a randomized controlled trial. J Clin Monit Comput. 2020;34(2):253-9.

14. Fassaert LMM, Borst GJD, Pennekamp CWA, et al. Effect of phenylephrine and ephedrine on cerebral (tissue) oxygen saturation during carotid Endarterectomy (PEPPER): a randomized controlled trial. Neurocrit Care. 2019:31(3):514-25.

15. Kussman BD, Laussen PC, Benni PB, et al. Cerebral oxygen saturation in children with congenital heart disease and chronic hypoxemia. Anesth Analg. 2017;125:234-40.

16. Eyeington $\mathrm{CT}$, Ancona P, Osawa EA, et al. Modern technology-derived normative values for cerebral tissue oxygen saturation in adults. Anaesth Intensive Care. 2019;47:69-75.

17. Ishiyama T, Kotoda M, Asano N, et al. Effects of hyperventilation on cerebral oxygen saturation estimated using near-infrared spectroscopy: a randomised comparison between propofol and sevoflurane anaesthesia. Eur J Anaesthesiol. 2016;33:929-35.

18. Dhabangi A, Ainomugisha B, Cserti-Gazdewich C, et al. Cerebral Oximetry in Ugandan children with severe Anemia: clinical categories and response to transfusion. JAMA Pediatr. 2016;170:995-1002.

19. Fan $X$, Lin $L$, Li G, et al. Do cerebral and somatic tissue oxygen saturation measurements correlate with each other during surgery. J Clin Monit Comput. 2019;34(3):483-90.

\section{Publisher's Note}

Springer Nature remains neutral with regard to jurisdictional claims in published maps and institutional affiliations. 